\title{
Questions on drug pact
}

\section{Boston}

THE Harvard-affiliated Dana-Farber Cancer Institute has signed a cooperative research agreement with a leading pharmaceutical company that is raising anew questions about just how closely a university should collaborate with commercial interests.

In the arrangement, announced last month, Dana-Farber will receive up to $\$ 100$ million over the next ten years from Sandoz Pharmaceuticals Ltd, the US subsidiary of the Swiss company. The two will cooperate to develop anticancer drugs based on increased knowledge of cell signal transduction. Many researchers in the field believe that they now understand cellular signalling processes well enough to begin trying in earnest to develop drugs that will target specific signal transduction defects - problems in cells' chemical signals that give rise to the

The agreement, due to begin on 1 January 1992, marks one of the largest investments so far by a pharmaceutical company in an academic research and teaching institution. But perhaps the most noteworthy feature of the plan is the way it is designed to pair academic researchers and corporate chemists in what David Livingston, vice president of Dana-Farber calls a "joint discovery" process.

The Dana-Farber Institute will devote roughly 10 per cent of the work time of its scientific staff to Sandoz projects. In addition, the arrangement calls for about 100 Sandoz chemists to work at the Dana-Farber side by side with its more than 400 researunregulated growth of cancer cells.

chers and postdoctoral fellows. Finally, in a departure for Harvard and other universities involved in large academic-corporate arrangements, patent rights and royalties from discoveries in the new programme will be shared by the two institutions rather than held by the academic institution and licensed to the company.

Livingston says he believes that the applied nature of the collaboration will fit easily within Dana-Farber's mission, because development of cancer treatment "is part of our mandate as a cancer center". But some critics worry that the arrangement could eventually weaken the institute's commitment to basic research. And Richard Kolodner, who conducts basic research at the Dana-Farber and chairs its division of cellular and molecular biology, says that many "legitimate questions" exist "about how something like this might influence hiring, or shift our mission."

As Kolodner observes, the Sandoz arrangement is unabashedly "goal-oriented", a characteristic that he said at least semantically separates it from previous collaborative plans involving Harvard. "Anyone here who wants some of this money will have to look at how their research might contribute to the development of drugs," Kolodner notes.

Such a feature could skew the direction of the institute's research, he says, but "it could also stimulate people to think about their research in new ways." All in all, Kolodner remains sanguine. "If you're at a cancer center, you can't help but think about the central problem at hand - treating and curing the disease."

Seth Shulman PHARMACEUTICAL PATENTS

\section{EC row looms over patents}

\section{London}

A European Commission proposal to extend the life of patents on new drugs to a maximum of 16 years after a drug's commercial launch (see Nature 344, 482; 1990) has been rejected by the British government, to the annoyance of UK pharmaceutical companies. The British rejection of the plan, which aims to bring European drug patenting in line with US and Japanese practice, means that a row is likely when ministers from European Communities (EC) member states meet to discuss the proposal later this year - France and Italy have already passed their own laws based on the Commission's ideas.

The problem facing European pharmaceutical companies is that drugs must be patented before clinical trials begin. By the time a drug is licensed for commercial use, a 20-year patent often has only eight years left to run. After this time, cheaper 'generic' copies of the drug can be sold, made by companies that have not had to shoulder the burden of high research and development costs.

The UK government says it will support the extension of drug patents, but only up to 13 years from a drug's launch. (The maximum effective length of patent protection in the United States is now 14 years, and in Japan 15 years.) The Commission's plan goes further than is necessary to help European companies compete with their US and Japanese competitors, said industry minister Lord Hesketh to the House of Lords, and the effect would be to discriminate against generic companies, and increase the costs of drugs.

However, the Association of the British Pharmaceutical Industry, which includes generic manufacturers among its membership, opposes the government's stand.

Apart from Britain, most of the other EC states with large pharmaceutical industries are in agreement with the Commission's plan, although the less-industrialized countries of southern Europe are expected to oppose the extension.
Peter Aldhous

\section{Census sex puzzle}

\section{New Delhi}

INDIA added another 160 million people in the past ten years to bring its population to 844 million. According to the 1991 census, the growth rate decreased by only 1.2 per cent compared to the previous decade.

Demographers are puzzled because the ratio of females to males in the population has declined, following an upward swing measured in the 1981 census. There are now 929 females for every 1,000 males, as compared with 934 in 1981.

At the turn of the century, India had 972 females for every 1,000 males, but the ratio had been steadily falling until the 1981 census. The reasons for the uneven sex ratio included a preference for male children, resulting in neglect of female babies, as well as a relative gap in health conditions between the two sexes - factors that many hoped had started to change.

The fact that the female/male ratio has fallen back since 1981 despite numerous women-centred health and nutrition programmes has set off a debate. Feminist groups believe that one cause is the selective abortion of females after sex selection tests offered by private clinics, which are mushrooming in cities and even small towns. Demographers, however, say the practice is not so widespread as to affect the sex ratio, and have called for an indepth study to look for other reasons.

K. S. Jayaraman

\section{SOUTH AFRICA - Saving the shark
Sating}

\section{Johannesburg}

South Africa is to become the first nation to give official protection to the great white shark, Carcharodon carcharias. The Minister of Environment Affairs, Louis Pienaar, announced on 11 April that regulations to protect the species in South African waters will be promulgated shortly.

The legislation was necessary, Pienaar said, because international trophy hunters are starting to focus their attention on the South African coast. The shark's jaws command up to $R 12,000$ as trophies, and populations of the predator have been decimated in some parts of the world.

In addition to making it illegal to catch great whites without permits, the legislation will forbid the sale of the species.

In future, permits will be issued only for research purposes or to the Natal Sharks Board, which is responsible for catching approximately 50 juveniles of this species each year in the shark nets that protect bathing beaches. The effect of the conservation measures on the local great white population will be monitored by Dr Len Compagno of the Shark Research Centre at the South African Museum, who is conducting research on its ecology.

Michael Cherry 